\title{
The function of Interfaith Forum (FKUB) in The Social System Of Interfaith Tolerance Establishment in West Pasaman Regency
}

\author{
Ferdi Ferdian $^{1}$, Afrizal $^{2}$, Elfitra ${ }^{3}$ \\ \{eljanma.ferdi@gmail.com ${ }^{1}$ \} \\ Department of Sociology, Andalas University, Indonesia
}

\begin{abstract}
This article is about creating tolerance among followers of different religions at the district level. Interfaith Forum (FKUB) ranging from national to district level was established by the government after the reform (2006) to create harmony among religious communities in Indonesia. This policy is a joint policy of the Minister of Religious Affairs and Minister of Home Affairs based on the view that the religious conflicts that occur can be controlled by facilitating communication between different religious leaders. This article will present the results of research on the function of FKUB to create tolerance among people in the regency of West Pasaman, which consists of different religions. The focus of research is on activities that were carried out to maintain harmony among people in the regency of West Pasaman. By using qualitative research data and Functional Structural Theory, this article will show that to create harmony among religious people in West Pasaman FKUB perform various activities namely investigation and mediation. Furthermore, this article describes the investigation that has been done and its effect on the creation of harmony of religious life. By playing the role of investigation and mediation, West Pasaman FKUB occupies an integration position in the social system of religious tolerance establishment in Pasaman Barat Regency and plays a role as a guardian of interreligious harmony. Besides, that will be shown in this article, FKUB West Pasaman contribute safety valve function in maintaining security stability in West Pasaman District
\end{abstract}

Keywords: tolerance among the followers of a religion, religious harmony, FKUB, mediation, religious conflicts.

\section{Introduction}

Indonesia is not only known as a country that is rich in natural resources, but also known for its cultural diversity, because it consists of various ethnicities, ethnicities, races, cultures, and religions that inhabit this country, from Sabang to Merauke. This diversity has long colored the social life of the Indonesian people. Until now, the portrait of diversity has become a fact of life that cannot be avoided anymore.

There are at least a few records of violent incidents that have occurred in this country, such as the Situbondo riots in October 1996. Similar riots also occurred in Tasikmalaya at the end of 1996. Previously (1990), a significant case to be raised here was when the sensitivity of the Islamic period was torn apart by the act of Arswendo Atmodiloto who held a quiz on the Monitor Tabloid which was chirping the Prophet, the result of which was to harass the Muslims of 1996. Then in early 1997 a similar conflict broke out in Rengasdengklok. In 1998 the Ketapang 
Incident broke out which then continued to the Ketapang tragedy. In the same year, coinciding with the Eid al-Fitr the Ambon incident broke out. As a continuation of this conflict, there were inter-religious disputes in Halmahera and Poso. During students, demonstration there was harassment (unclean waste) at the DPR's First Level North Sumatra mosque in 1999, and on May 28, 2000 there were bombings of houses of worship in Medan [1].

In addition to the above events there are also other religious cases, including: (1) In 2007, the church members of the Philadelphian Church who were worshiping experienced rejection from residents who were consolidated by local community leaders who were supported by the Muslim Community Communication Forum (FKUI); (2) The same thing happened in Bogor in 2008, the government suspended the permit to establish the GKI Yasmin church due to pressure and rejection from the community; (3) In 2015, in Tolikara, Papua there was also a conflict that began with the incident of burning mosques by the Injel Church congregation when Muslims wanted to hold Eid al-Fitr prayers, resulting in 2 deaths and at least 96 Muslim houses in burn; (4) At the DKI Jakarta post-conflict local election party in 2016 yesterday, religious sentiment became a concern at the democratic party, this was due to the gubernatorial candidates from non-Muslims, so that the illegitimate issue of choosing infidels became very large leaders in Jakarta, so that the community became divided between pros and cons of non-Islamic leaders [2]

Religious diversity is one of the realities that always color the nuances of community life in Indonesia. Recognition of diversity, especially religious diversity is the starting point for religious freedom for every human being. Even Natsir asserts that "religion occupies an urgent, vital and strategic position in human life" [3]. Religion is further positioned as a benchmark and criteria in determining something that is wrong or right, so that religious diversity. Besides being a reality at the normative-theological conceptual level, is also a reality at the sociologicalpolitical empirical level. These two dimensions cannot be separated, given that religion is a norm system that has manifested itself in the lives of every religious community, to create national unity and unity, harmony between religious communities is an important pillar that needs to be seriously managed.

Historically, the Indonesian people have been reminded for a long time to live side by side peacefully in a society of various ethnicities, religions, races, and groups. Moreover, the Indonesian people are also called upon to be able to understand each other, live and carry out a common life in order to create unity and unity in the nuances of these differences as the Indonesian state motto, Bhinneka Tunggal Ika (different but still one). It means that we are always reminded to appreciate and appreciate the differences in SARA as an element that unites this nation and not as a reason for triggering conflict. An invitation like this, in social studies, is a form of socialization of values contained in diverse societies [4].

Indonesia as a unitary state has the potential or vulnerable to the emergence of conflict because of the diversity of ethnic groups, languages, religions, races and ethnicities and groups that are present in the midst of people's lives. This diversity is then often the trigger for the emergence of social conflict in the community. The more widespread and widespread opposition lately is a sign of a decline of tolerance in society. This condition is seen by the increasing conflict between the SARA and the emergence of some movements that 'seem to want to separate themselves from the Republic of Indonesia due to dissatisfaction and differences in interests. If this condition is not immediately handled and managed properly, then it is possible to have an impact on national disintegration. Moreover, Geertz's research reveals that Indonesian pluralism has been divided into subsystems that are more or less independent, each of which is bound to a strong bond and primordial spirit [5]. 
Indonesian with its diverse society has the potential and is very vulnerable to ethnic violence, both culturally and politically constructed. If religious entities or other primordial elements appear on the political stage as the most dominant principle in the regulation of the state and nation, let alone wishing to change the system that has been in effect, it is not impossible that the threat of national disintegration in the sense that actually will occur in Indonesia.

The structure of a pluralistic society it must keep the seeds of contradiction commonly called latent conflict. This conflict originated from differences in views, steps and understanding and clashes between groups and between individuals [5]. Conflict will occur if the problems that arise on the surface do not find a settlement point, it will lead to physical violence between the conflicting parties.

Conflict events that have or will occur must be appropriately managed so that harmony is created. In order to take care of the harmony, the 1945 Constitution is a constitution of mutual cooperation. Whereas in Article 33 of the 1945 Constitution, Indonesia's economic system is referred to as family based. The value of the One God Almighty principle, kinship and mutual cooperation is a factor of community unity that dampens opposition in diverse societies. Diversity in Bhinneka Tunggal Ika, requires the birth of harmony or balance. In it contained elements of moderation which in Islamic teachings are referred to as "mid" (was then) which has the core of justice. The attitude of moderation which is to reduce the opposition gives birth to the mid-principle with the core of justice.

Moreover, justice is what gives birth to the harmony that contains harmony and balance. That is why at the opening of the 1945 Constitution, the Indonesian state's axiology, namely eternal peace, was based on social justice. Social justice is can reduce the potential for conflict and create peace.

To create harmony in a multicultural society, the Indonesian people have made various efforts which can be broadly grouped into two parts. First is to build a nuance of diversity through the growth of awareness of the meeting point (sentence of sawa') in the esoteric level of each religion more intensely and sincerely, so that the harmony of the life of the nation and state can be realized. The second is constitutional and political efforts, as evident in the stipulation of laws, regulations and some stipulations in regulating the life of the multicultural community. The maintenance of the harmony of the various Ummah lives can be clearly seen in the 1945 Constitution article 29 paragraph (1) and (2) that the Indonesian state is a country based on the One God Almighty, so that the state guarantees the independence of every citizen to embrace his religion and worship according to religion and belief. Even in the most recent ideas in the 1998 MPR Special Session, formulated one of the reform efforts in the field of religious life in the form of fostering inter-religious harmony as well as the formation and empowerment of networks between religious communities in each region.

In addition, some government regulations concerning the formation of religious awareness based on community awareness and the establishment of the Religious Harmony Forum (FKUB) are also used as a means of unifying these diverse communities. In this case, FKUB seems to be a strategic step taken by the government in building, guiding, and maintaining harmony between religious communities at the national, provincial and district / city levels in Indonesia as stated in the Joint Regulation of the Minister of Religion and Minister of Home Affairs No. 9 and 8 of 2006. [1].

There are at least some religious cases that were successfully resolved by the FKUB, including: (1) The burning case of a mosque in Tolikara in 2015. This case occurred to coincide with the implementation of Eid al-Fitr prayer $1436 \mathrm{H}$, which was due to tensions between the Gospel Church in Indonesia (GIDI) Tolikara with Muslims in Tolikara. The case that became 
a national issue also received a response from many parties, ranging from the regional government, the central government such as the TNI, the National Police, the relevant Minister, even the president reacted. In addition, the Papua FKUB, as an institution with a religious harmony mission, played a very significant role in this case, including making the Special Team of Tolikara Incident Facts and Data Seekers, becoming a facilitator / mediator to reconcile the two parties who were involved so that on 29 July 2015 was born Mutual agreement for harmony and peace to embrace peace and harmony. (Report on the Data and Facts of the Tolikara Incident on 11 July 2015 by the FKUB of Papua Province); (2) The burning of the church in 2016 in Aceh Singkil, in this incident the Aceh Singkil FKUB made an effort to reconcile the Muslim and Christian parties by becoming a mediator and finding the best solution which was also assisted by the local government, police and religious and community leaders, as well as FKUB also socializes the Joint Ministerial Regulation No. 9 and No. 8 of 2006 concerning the rules for the establishment of places of worship.

In a more narrow locus, this diversity phenomenon can also be seen more clearly, one of them is from the portrait of people's lives in West Pasaman. West Pasaman which is one of the regencies in West Sumatra province that is ethnically, religiously and culturally diverse. BPS (Central Statistics Agency) Pasaman Barat records there are six (6) ethnic communities, namely Minangkabau, Batak, Mandailing, Java, Malay and Nias. They live and inhabit Pasaman Barat simultaneously by making one of the religions - Islam, Protestantism, Catholicism or Hinduism - as their belief in carrying out life [6]. This condition shows that Pasaman Barat society is classified as a plural, heterogeneous and plural society. Multicultural society is a society consisting of two or more elements that live side by side in a social entity.

The following is the population of Pasaman Barat Regency based on religion in each subdistrict:

Table 1. Population based on religion in West Pasaman

\begin{tabular}{lllllll}
\hline No & Districts & Islam & Protestan & Budhish & Chatolic & Total \\
\hline 1 & Gunung Tuleh & 21.219 & - & - & - & 21.219 \\
2 & Kinali & 70.393 & 687 & - & 1.165 & 72.245 \\
3 & Pasaman & 75.127 & - & - & - & 75.127 \\
4 & Lembah Melintang & 47.852 & 29 & - & 10 & 47.891 \\
5 & Sungai Beremas & 25.205 & 10 & - & 10 & 25.225 \\
6 & Ranah Betahan & 26.438 & - & - & - & 26.438 \\
7 & Talamau & 26.922 & - & - & - & 26.922 \\
8 & Sasak Ranah Pesisir & 14.667 & - & - & 19 & 14.686 \\
9 & Sungai Aur & 36.171 & 113 & 76 & 179 & 36.539 \\
10 & Koto Balingka & 29.838 & 32 & - & 8 & 29.878 \\
11 & Luhak Nan Duo & 40.826 & 724 & - & 1.065 & 42.615 \\
\hline Total & & 414.658 & 1.595 & 76 & 2.456 & 418.785 \\
\hline
\end{tabular}

Source: BPS data; West Pasaman in 2017's.

Ethnic and religious diversity is not impossible to be able to create disputes and disputes, which in turn can lead to violence in the community. One of them, for example, was photographed through the destruction of houses of residents who lived in Luhak Nan Duo District in 2012. The house was "transformed" into a Church (place of worship) because the place of worship was far from their residence so that the incident sparked anger for the Muslims, who in the end they forcibly broke the cross installed outside the house and sealed the house. In addition, in 2014 there was also the burning of two churches located in Kinali District at the same time, namely the Church of St. Maria was appointed to Heaven and Theresia Church. Until 
now, it is not known who the person who carried out the arson, and the West Pasaman FKUB quickly resolved this incident [7].

This incident is a reason that reinforces that differences in religion and belief are one of the causes of conflict in a pluralistic society. So after the issuance of the Joint Regulation of the Minister of Religion and the Minister of Home Affairs No. 9 and 8 of 2006, the Government of West Pasaman rushed to form a forum for harmony between religious communities which was named the Pasaman Barat Ummat Beragama Harmony Forum (FKUB). FKUB Pasaman Barat was established on January 8, 2007 based on the Decree of the Regent Number 188.45 / 04 / BUP-PASBAR / 2007 by the mandate of PBM, namely as a forum for religious leaders in realizing unity and harmony between religious communities and for the success of community development in West Pasaman Regency.

Based on the formulation of the above problem, this study aims to find out the function of the West Pasaman FKUB in the realization of religious harmony in Pasaman Barat. While the benefits of this study theoretically (academically) contribute to students in completing studies that lead to the development of knowledge related to religious harmony. As well as practically the results of this study can provide input for policymakers to be able to embrace all religious followers so that policy jealousy does not occur in the community.

\section{Methods}

The implementation of this research for one month, on July. The location of this study was carried out in West Pasaman. This study uses primary and secondary data. The primary data were collected using interview guidelines to informants and secondary data obtained from relevant agencies. This study uses functional, structural theory by Talcott Parsons. Parsons argues that function is a cluster of activities directed to meet one or more system requirements. Parsons states that four functional imperatives or functions exist in a social system, namely Adaptation, Goal or goal attainment, Integration, and Latency or pattern maintenance. Social institutions are recognized as the core of the social order. He contributed to showing accurately how social institutions were formed and how they walked.

\section{Result and Discussion}

From the research conducted for one month, the following results were found: The research was conducted in West Pasaman, especially the Inter-Religious Harmony Forum. The results of the study explained that FKUB West Pasaman conducted investigations and mediations in creating inter-religious harmony. In functional, structural theory pioneered by Talcott Parsons that function is a cluster of activities directed to meet one or several system needs. In creating inter-religious harmony, the West Pasaman FKUB conducted investigations and mediations.

\subsection{Investigation}

Investigation is an effort of research, investigation, investigation, disbursement, examination, and collection of data, information and other findings to find out / prove the truth or even a factual error which then presents conclusions on a series of findings and sequence of events. In creating religious harmony, FKUB West Pasaman investigated a first way; FKUB West Pasaman received reports from the public that there had been a conflict between religious 
believers somewhere. One example is the establishment of a house of worship where the house of one of the congregations (Christians) was conjured up as a place of worship in 2014 in Kinali Sub-district, West Pasaman Regency.

The worship activity unsettled the community around the house of worship so that the community gave a warning to the Jamaat not to continue their worship activities. Giving warnings has been carried out many times by the community to the Jamaat but not responded to so that the burning of the house of worship.

Based on the case, FKUB West Pasaman received reports from the public. In responding to the case, the West Pasaman FKUB quickly coordinated fellow administrators with religious leaders. After that, the coordination between FKUB administrators was completed, the coordination efforts will be extended to other agencies, such as the police, the regional government represented by the Kesbangpol service (National and Political Unity) and the Kakanmenag (Head of the Ministry of Religion) West Pasaman Regency. The management of the West Pasaman FKUB along with related institutions coordinated in the West Pasaman Regent's Office Hall.

Coordination aims to discuss reports received from the community namely conflict between religions. All parties were asked to provide information received from the public regarding the religious conflict that occurred. In the coordination process, all parties regulate and determine the conflict resolution mechanism that will be carried out in the field. This means that the conflict resolution mechanism that will be carried out in the field is the result of a joint agreement of all parties, both the FKUB West Pasaman management, the police, the regional government, and the West Pasaman religious ministry. After the coordination is complete, then the steps will be taken to the location of the incident and of course in order to find concrete information behind the incident. The steps taken by the administrators of the West Pasaman FKUB and related institutions are direct examination or investigation into the field based on reports received from the public. Examinations carried out include the causes of conflicts between religions, who is involved and the impact of the conflict.

\subsection{Mediation}

Mediation is an effort to resolve the conflict by involving a neutral third party, who does not have decision-making authority that helps the parties to a settlement reach a solution (solution) received by both parties. In addition to investigations, mediation is also a way that is done in resolving inter-religious conflicts in West Pasaman. Based on religious conflicts that occurred in West Pasaman such as one of the concerns experienced by the community due to the establishment of houses of worship by the Christian Religion, West Pasaman FKUB acts as a mediator in resolving the conflicts that occurred. Besides that, it also involved other agencies such as the police, the regional government represented by the Kesbangpol service (National and Political Unity) and the Kakanmenag (Head of the Ministry of Religion) West Pasaman Regency.

In the mediation process of the West Pasaman FKUB administrators along with related agencies went directly to the field to resolve the conflict. The way is to bring together the two parties to the dispute, for example, the community and the party that established the house of worship. FKUB Pasaman Barat asks for aspirations from both parties, then accommodates all aspirations from both parties. FKUB Pasaman Barat seeks to find a solution regarding the case of the establishment of places of worship and explain the government regulations related to the establishment of houses of worship namely Joint Ministerial Decree (SKB) number 9 and number 8 2016. The rules are: list of names and Identity Card (KTP) worshipers at least 90 people authorized by local officials in accordance with regional boundaries, local community 
support of at least 60 people authorized by the Lurah / Village Head / Wali Nagari, written recommendation from the head of the district / city religious department office and district FKUB written recommendations/city.

Based on the mediation carried out by FKUB Pasaman Barat and related agencies, the form of the results of the agreement obtained was that religious activity were not resumed. This solution was taken in response to public unrest. Houses of worship that began to be built which did not meet the rules by the SKB regulations of the two ministers were dismissed. These steps were agreed upon in order to create justice and inter-religious harmony in West Pasaman.

\section{Conclusion}

Based on the results of the above study it can be concluded that in creating inter-religious harmony in West Pasaman, the FKUB West Pasaman made various efforts including the investigation stages and the mediation stages. Where at the stage of the investigation, FKUB West Pasaman seeks complete information about any religious conflicts that occur in the middle of religious communities. It is done to be able to find redness where the background of the problem occurs and to find a point of peace. At the mediation stage, FKUB brings together the two conflicting parties to be reconciled and to seek a peace agreement between the two parties.

\section{References}

[1] Harahap, Syahrin. 2011. Teologi Kerukunan. Jakarta: Prenada

[2] CRCS. 2015. Serial Laporan Kehidupan Beragama di Indonesia.

[3] Faisal, 2016. Hubungan Antar Agama; Hubungan Islam Kristen Menurut Muhammad Natsir. Padang: Hayfa Press

[4] Qamar, Mujamil. 2012. Fajar Islam Indonesia; Kajian Komprehensif atas Arah Sejarah dan Dinamika Intelektual Islam Nusantara. Bandung: Mizan.

[5] Setiadi, Elly M dan Usman Kolip. 2011. Pengantar Sosiologi "Pemahaman Fakta dan Gejala Permasalahan Sosial: Teori, Aplikasi dan Pemecahannya. Jakarta: Kencana Prenada Media Goup.

[6] BPS Pasaman Barat. 2017, Pasaman Barat dalam Angka, Padang: CV. Zigiran

[7] Interview, Sufrinas, Chairperson of FKUB Pasaman Barat, August 24, 2017). 